\title{
Randomized, placebo-controlled trial of low molecular weight heparin in active ulcerative colitis
}

Citation for published version (APA):

de Bievre, M. A., Vrij, A. A., Schoon, E. J., Dijkstra, G., de Jong, A. E., Oberndorff-Klein Woolthuis, A. H., Hemker, H. C., \& Stockbrugger, R. W. (2007). Randomized, placebo-controlled trial of low molecular weight heparin in active ulcerative colitis. Inflammatory Bowel Diseases, 13(6), 753-758.

https://doi.org/10.1002/ibd.20085

Document status and date:

Published: 01/01/2007

DOI:

10.1002/ibd.20085

Document Version:

Publisher's PDF, also known as Version of record

\section{Please check the document version of this publication:}

- A submitted manuscript is the version of the article upon submission and before peer-review. There can be important differences between the submitted version and the official published version of record.

People interested in the research are advised to contact the author for the final version of the publication, or visit the DOI to the publisher's website.

- The final author version and the galley proof are versions of the publication after peer review.

- The final published version features the final layout of the paper including the volume, issue and page numbers.

Link to publication

\footnotetext{
General rights rights.

- You may freely distribute the URL identifying the publication in the public portal. please follow below link for the End User Agreement:

www.umlib.nl/taverne-license

Take down policy

If you believe that this document breaches copyright please contact us at:

repository@maastrichtuniversity.nl

providing details and we will investigate your claim.
}

Copyright and moral rights for the publications made accessible in the public portal are retained by the authors and/or other copyright owners and it is a condition of accessing publications that users recognise and abide by the legal requirements associated with these

- Users may download and print one copy of any publication from the public portal for the purpose of private study or research.

- You may not further distribute the material or use it for any profit-making activity or commercial gain

If the publication is distributed under the terms of Article $25 \mathrm{fa}$ of the Dutch Copyright Act, indicated by the "Taverne" license above, 


\title{
Randomized, Placebo-Controlled Trial of Low Molecular Weight Heparin in Active Ulcerative Colitis
}

\author{
M.A. de Bièvre, $M D,{ }^{*} A . A$. Vrij, $M D{ }^{+}{ }^{\dagger}$ E.J. Schoon, $M D,{ }^{\neq}$G. Dijkstra, $M D{ }^{\S}$ A.E. de Jong, $M D,{ }^{\S}$ \\ A.H. Oberndorff-Klein Woolthuis, MD, H.C. Hemker, MD, and R.W. Stockbrügger, $M D^{\mid}$
}

\begin{abstract}
Background: In several open and 1 controlled trial, unfractionated heparin was effective in the treatment of active ulcerative colitis (UC). Low molecular weight heparin (LMWH) had a similar effect in several open studies.
\end{abstract}

Methods: We studied the efficacy, safety, and tolerability of LMWH in mild to moderately active UC in a randomized, doubleblind, placebo-controlled trial. In all, 29 patients with a mild or moderate recurrence of UC during salicylate treatment were randomized to receive either reviparin 3,436 IU $(n=15)$ subcutaneously twice daily or placebo $(n=14)$. The study period was 8 weeks. Treatment was discontinued if there was no improvement at 4 weeks or at any disease progression. Primary outcome measure was clinical improvement at 8 weeks measured by the Colitis Activity Index (CAI) and the Clinical Symptoms Grading (CSG, based on the CAI). Endoscopic and histologic grading and quality of life as measured by the Inflammatory Bowel Disease Questionnaire (IBDQ) were secondary outcome measures. Patients were closely monitored for adverse events.

Results: Twenty of 29 patients finished the 8-week treatment period (reviparin versus placebo: 11 versus 9; $P=0.70$ ). There was no difference in CSG, CAI, endoscopic and histologic grading, or IBDQ. Treatment was well tolerated and no serious adverse events occurred.

Conclusion: In this study, treatment with LMWH showed no significant clinical advantage compared to placebo in mild to moderately active UC.

(Inflamm Bowel Dis 2007;13:753-758)

Key Words: heparin, low molecular weight heparin, ulcerative colitis, treatment

Received for publication November 9, 2006; accepted November 15, 2006.

From the *Atrium Medical Center, Heerlen, Netherlands; 'Twenteborg Hospital, Almelo, Netherlands; ${ }^{\ddagger}$ Catharina Hospital, Eindhoven, Netherlands; `University Hospital, Groningen, Netherlands; 'University Hospital, Maastricht, Netherlands.

Reprints; M.A. de Bievre, Atrium Medical Centre, Henri Dunantstraat 5, Heerlen, 6419 PC, Netherlands (e-mail: mdebievre@wanadoo.nl).

Copyright (C) 2007 Crohn's \& Colitis Foundation of America, Inc.

DOI 10.1002/ibd.20085

Published online 26 January 2007 in Wiley InterScience (www.interscience. wiley.com), n the majority of cases the clinical course of ulcerative colitis

(UC) is characterized by exacerbations with abdominal pain and frequent bloody stools, alternating with periods of remission. The current treatment strategy is aimed at inducing remission with 5-aminosalicylates (5-ASA) and/or corticosteroids or, in refractory cases, with cyclosporin or anti-TNF $\alpha$, and maintaining remission with 5-ASA and/or azathioprine. All these drugs can have significant side effects; also, a proportion of patients are refractory to them and might require colectomy.

In 1952, in the Netherlands, the first article was published describing the use of heparin as an anti-inflammatory drug in cases of acute polyarthritis. ${ }^{1}$ This was followed by a series of studies from Russia showing some success with heparin treatment in rheumatoid arthritis. ${ }^{2,3}$ These results led to the assumption that there might be a place for the clinical application of the anti-inflammatory properties of heparin. In 1982 a Russian study reported a clinical benefit with unfractionated heparin (UFH) in patients with active UC. ${ }^{4}$

In 1991 Gaffney et $\mathrm{al}^{5}$ described 3 patients with active UC who showed a good response to treatment with UFH; the first of these 3 patients had reported a remission of his colitis during treatment for a deep vein thrombosis. Successful treatment in a further 6 of 7 patients was reported by the same group in $1995 .^{6}$

Subsequently, several studies have been published describing the treatment of active UC with heparin, mostly in the UFH form, 2 of which were controlled, comparing heparin to corticosteroids. ${ }^{7,8}$ The other studies were performed in an open, uncontrolled manner. ${ }^{9,10}$ The results varied, with an overall tendency toward a beneficial effect of UFH. Very few side effects have been reported. Three studies performed with low molecular weight heparin (LMWH) also showed benefit, with clinical improvement rates ranging from 58\%-91\%. ${ }^{11-13}$ The treatment was well tolerated. None of these 3 studies, however, was controlled.

In view of these results we designed a study to test the hypothesis that LMWH is an effective drug in the treatment of UC.

\section{MATERIALS AND METHODS}

\section{Study Design}

We performed a randomized, double-blind, 2-center trial comparing reviparin (Clivarin, Knoll, Ludwigshafen, 
Germany) 3,436 IU twice daily to placebo in patients with mild to moderately active UC.

\section{Patient Population}

Between August 1996 and February 2000 a total of 29 patients were enrolled at the Departments of Gastroenterology of the University Hospitals of Maastricht and Groningen, The Netherlands. Patients with mild to moderately active UC (diagnosis based on Lennard-Jones criteria ${ }^{14}$ ), with a severity score of 4-14 according to the Truelove classification ${ }^{15}$ were eligible. The active colitis could either be the first manifestation or an exacerbation of known disease. Sigmoidoscopy had to have been performed less than 2 weeks before the start of treatment.

Excluded from the trial were patients with proven Crohn's disease, infectious colitis (excluded through stool cultures), ischemic colitis, or irradiation colitis. Use of oral or rectal corticosteroids or other immunosuppressive drugs was prohibited within 4 weeks before study entry. Also excluded were patients with known thromboembolic disposition or current use of anticoagulants, patients with known or suspected bleeding tendency, or with regular use of nonsteroidal anti-inflammatory drugs (NSAIDs), including low-dose aspirin. Previous adverse events to heparin therapy, known active ulcer disease, serious hepatic disease (ASAT $>3 \times$ upper limit) or renal failure (serum creatinine $>300 \mathrm{mmol} / \mathrm{L}$ ) as well as pregnancy or breast feeding in female patients were other exclusion criteria.

Written informed consent was obtained from all patients. The protocol was approved by the Ethical Committees of both participating hospitals.

\section{Treatment}

After randomization (random allocation), patients received either reviparin (Clivarin, MW 3,900 Da) 3,436 IU Pharm Eur / $0.6 \mathrm{~mL}$ (corresponding to 10,000 U of unfractionated calcium heparin) subcutaneously or placebo twice daily. The drug and placebo were made available in individually packed disposable syringes. Drugs were administered through self-injection.

All patients were on stable treatment with either salazopyrine $(n=4)$ or mesalazine $(n=20) 1 \mathrm{~g} 2-3$ times daily or olsalazine $(n=5)$ in a comparable dose.

Treatment was intended to last 8 weeks. Control visits were planned at $1,2,4,6$, and 8 weeks. Treatment was discontinued if there was no improvement after 4 weeks according to the Clinical Symptom Grading (CSG) ${ }^{16}$ and/or Clinical Activity Index $(\mathrm{CAI})^{17}$ or in any patient with progression of disease activity at any control visit. Improvement was defined as a reduction of the CSG and CAI score of more than 4 points and 6 points, respectively (Tables 1,2$)$. Other reasons for discontinuation were heparin-induced thrombocytopenia (HIT) type 2 $2^{18,19}$ (thrombocytes below 100
TABLE 1. Colitis Activity Index (CAI)

\begin{tabular}{|c|c|}
\hline Symptom & Day \\
\hline Diarrhea $\mathrm{x} /$ day & Score: \\
\hline $0-2$ & 0 \\
\hline $3-4$ & 1 \\
\hline $5-6$ & 2 \\
\hline $7-9$ & 3 \\
\hline$>10$ & 4 \\
\hline Diarrhea at night & Score: \\
\hline No & 0 \\
\hline Yes & 1 \\
\hline Fecal blood loss (\%) & Score: \\
\hline 0 & 0 \\
\hline$<50$ & 1 \\
\hline$>50$ & 2 \\
\hline 100 & 3 \\
\hline Incontinence for feces & Score: \\
\hline No & 0 \\
\hline Yes & 1 \\
\hline Abdominal pain & Score: \\
\hline None & 0 \\
\hline Mild & 1 \\
\hline Moderate & 2 \\
\hline Severe & 3 \\
\hline General well-being & Score: \\
\hline Perfect & 0 \\
\hline Very good & 1 \\
\hline Good & 2 \\
\hline Moderate & 3 \\
\hline Bad & 4 \\
\hline Terrible & 5 \\
\hline Abdominal tenderness & Score: \\
\hline None & 0 \\
\hline Mild, localized & 1 \\
\hline Mild to moderate, diffuse & 2 \\
\hline Severe or rebound tenderness & 3 \\
\hline Antidiarrhea medication & Score: \\
\hline No & 0 \\
\hline Yes & 1 \\
\hline Total score: $(\max =21)$ : & \\
\hline
\end{tabular}

$\times 10 \mathrm{E} 9 / \mathrm{L}$ ) or severe bleeding (defined as hemoglobin $[\mathrm{Hb}]$ $<5.0 \mathrm{mmol} / \mathrm{L}, \mathrm{Hb}>2.0 \mathrm{mmol} / \mathrm{L}$ below baseline value, blood loss with blood pressure $<80 / 50 \mathrm{mmHg}$ and/or need for blood transfusion). In patients in whom the study treatment was discontinued, conventional treatment with corticosteroids was initiated.

\section{Outcome Parameters}

The primary endpoint of the study was clinical improvement after 8 weeks of treatment. Disease activity was 


\begin{tabular}{lclc}
\hline TABLE 2. Clinical Symptom Grading (CSG) & \\
\hline Parameter/Grade & 0 & \multicolumn{1}{l}{1} & 2 \\
\hline Blood loss & None & Sometimes & Frequent \\
Mucus discharge & None & Sometimes & Frequent \\
Frequency of defecation & $<3 /$ day & $3-6 /$ day & $>6 /$ day \\
Consistency of feces & Normal & Semiliquid & Liquid \\
Tenesmus & Absent & Mild & Severe \\
Abdominal pain & Absent & Mild & Severe \\
Rectal pain & Absent & Mild & Severe \\
Nausea/ vomiting & Absent & Sometimes & Frequent \\
\hline
\end{tabular}

Maximum score $=16$.

assessed at entry and at every visit by means of the CAI (scale 0-21) and CSG (scale 0-16). Secondary endpoints included an Endoscopic Grading System ${ }^{16}$ (EGS; scale 0-18) recorded at sigmoidoscopy performed before entry and after 8 weeks. Biopsies were taken at $10 \mathrm{~cm}$ from the anus and from the mid-sigmoid and assessed according to a Histological Grading System ${ }^{16}$ (HGS; scale $0-12$ ) by 2 independent pathologists.

Quality of life was assessed at weeks 1,4 , and 8 by means of the Inflammatory Bowel Disease Questionnaire $(\mathrm{IBDQ})^{20}$. Safety parameters measured at every visit included $\mathrm{Hb}$, hematocrit (Ht), white blood count (WBC), platelets, creatinine, alkaline phosphatase (ALP), aspartate transaminase (AST), and alanine transaminase (ALT).

\section{Statistical Methods}

The sample size was based on categorical data ("Did the patient improve?"). For the expected proportion with specified outcome: $\mathrm{p}_{1}=$ improved on heparin 0.80 (based on previous uncontrolled studies $\left.{ }^{1-13}\right), \mathrm{p}_{2}=$ improved on placebo 0.20 . The common SD was 0.68 . Taking the power to be 0.85 and a 2 -sided significance level of 0.05 , the sample size was calculated to be 24 for each of the 2 groups.

Analysis was performed on an intention-to-treat basis with last value carried forward in case of premature discontinuation. The software used was SAS for Windows (v. 6.12; SAS Institute, Cary, NC). For qualitative parameters (categorical or ordered), frequency counts and percentages of each category were calculated by treatment group.

The significance of differences between placebo and LMWH-treated patients was analyzed with the Pearson chisquare test with asymptotic 2 -sided significance. For $2 \times 2$ tables, Fisher's exact test was computed. Group mean differences were calculated using unpaired $t$-tests for normally distributed variables or the Mann-Whitney Wilcoxon's test for skewed distributed variables.

\section{RESULTS}

\section{Patients}

Fifteen patients were randomized to receive reviparin and 14 to receive placebo (19 patients were included in the University Hospital Maastricht and 10 in the University Hospital Groningen). Demographic data and clinical characteristics of patients randomized to treatment are shown in Table 1. There was no difference between the 2 groups with regard to age, gender, or smoking habits. Mean duration and extent of disease, previous steroid treatment, and individual or family history of thrombosis or bleeding tendency were similar in both groups.

\section{Primary Efficacy Endpoint}

In the reviparin group 11/15 (73.3\%) patients completed the 8 weeks of treatment and in the placebo group 9/14 $(64.3 \%)(P=0.70)$. One patient in the placebo group was lost to follow-up after 2 weeks. In all other patients reason for discontinuation was either lack of efficacy or exacerbation.

At baseline the mean CAI and CSG levels were not significantly different between the reviparin- and placebotreated patient groups (Table 3). At 4 weeks the mean CAI was 7 (95\% confidence interval [CI]: 5-9) in both the reviparin and placebo group $(P=0.547)$, and at 8 weeks the mean CAI was 5 (95\% CI: 3-7) in the reviparin group and 6 (95\% CI: 3-8) in the patients treated with placebo $(P$ $=0.490$ ) (Fig. 1).

At 4 weeks the mean CSG was 5 (95\% CI: 3-7) in both the reviparin and placebo group $(P=0.693)$, and at 8 weeks the mean CSG was 4 (95\% CI: $1-6)$ in the reviparin group and 4 (95\% CI: $1-7)$ in the patients treated with placebo $(P$ $=0.759$ ) (Fig. 2).

TABLE 3. Demographic and Clinical Data at Baseline

\begin{tabular}{|c|c|c|c|}
\hline & $\begin{array}{c}\text { Reviparin } \\
(n=15)\end{array}$ & $\begin{array}{l}\text { Placebo } \\
(n=14)\end{array}$ & $P$ \\
\hline Age (yr) & 38.0 & 42.4 & NS \\
\hline \multicolumn{4}{|l|}{ Gender } \\
\hline male & $9(60 \%)$ & $7(50 \%)$ & NS \\
\hline Smoking & & & NS \\
\hline never & 4 & 2 & \\
\hline no & 8 & 11 & \\
\hline yes & 3 & 1 & \\
\hline $\begin{array}{l}\text { Previous corticosteroid } \\
\text { therapy }(n)\end{array}$ & $9(60 \%)$ & $9(64.3 \%)$ & NS \\
\hline CAI (min-max) & $9.87(5-16)$ & $9.14(3-13)$ & $\mathrm{NS}$ \\
\hline CSG (min-max) & $8.33(4-14)$ & $6.36(2-10)$ & $0.061(\mathrm{NS})$ \\
\hline $\begin{array}{l}\text { Mean duration of } \\
\text { disease (yr) (range) }\end{array}$ & $6(0-15)$ & $7(0-26)$ & NS \\
\hline
\end{tabular}




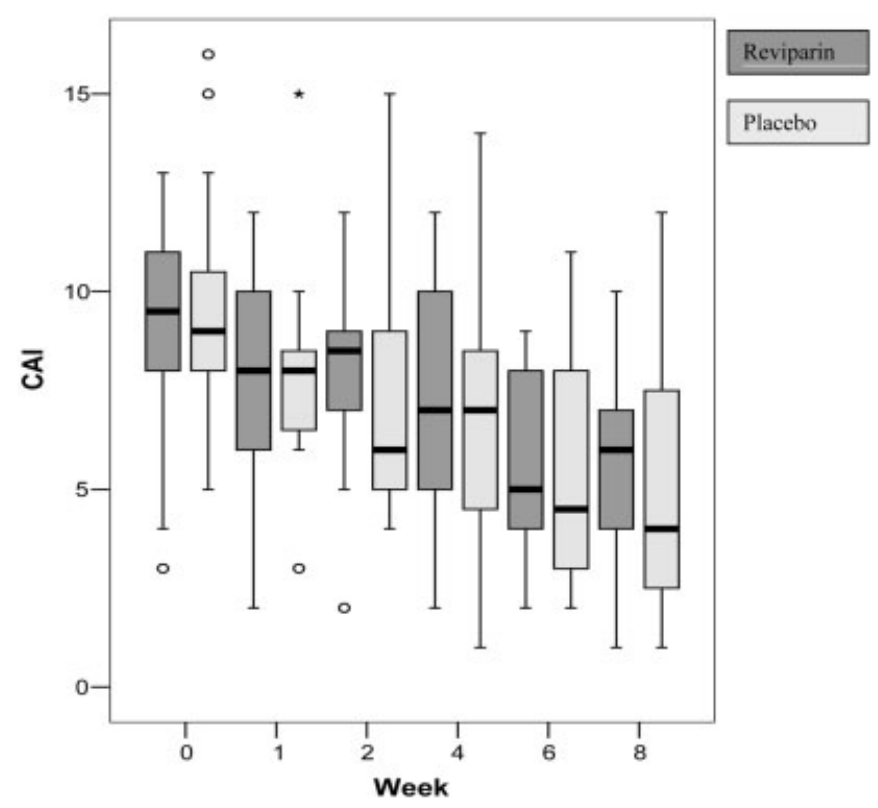

FIGURE 1. Box-Whisker plots of the CAI in reviparin- and placebo-treated patients at different time intervals, with outliers $(0)$ and extremes $\left(^{*}\right)$. No significant differences were observed between the 2 groups.

\section{Secondary Efficacy Endpoints}

The results of the secondary outcome measures are summarized in Table 4. There were no significant differences in either EGS, HGS, or IBDQ between the groups.

\section{Adverse Events}

There were no serious adverse events in either study group. There was no significant difference in adverse events between the 2 study groups (Table 5).

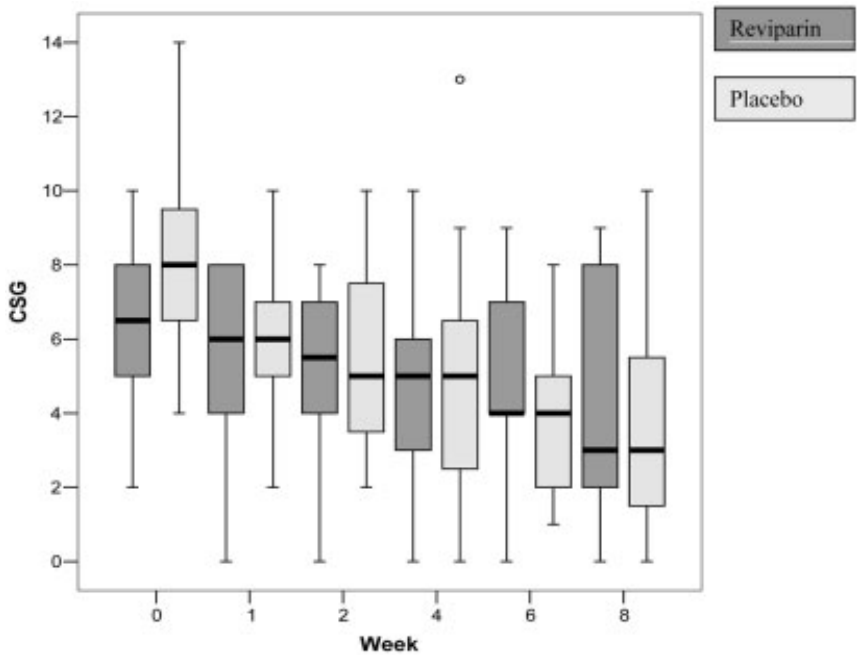

FIGURE 2. Box-Whisker plots of the CSG in reviparin- and placebo-treated patients at different time intervals, with outliers $(0)$ and extremes $\left(^{*}\right)$. No significant differences were observed between the 2 groups.
TABLE 4. Endoscopic, Histologic, and Quality of Life Outcomes

\begin{tabular}{lrrr}
\hline & Reviparin & Placebo & $P$ \\
\hline EGS & & & \\
$\quad$ Day 0 $(n)$ & $9.64(14)$ & $9.46(13)$ & 0.92 \\
$\quad$ Day 57 $(n)$ & $7.36(11)$ & $7.63(9)$ & 0.80 \\
$\quad$ Patients improved (\%) & $9(64.3)$ & $8(66.7)$ & 0.49 \\
HGS & & & \\
$\quad$ Day 0 $(n)$ & $2.93(15)$ & $3.93(14)$ & 0.20 \\
$\quad$ Day 57(n) & $2.00(11)$ & $3.11(9)$ & 0.33 \\
Patients improved (\%) & $10(66.7)$ & $7(53.4)$ & 0.41 \\
IBDQ & & & \\
$\quad$ Day 0 & 132.1 & 141.2 & 0.57 \\
Day 57 & 162.1 & 173.1 & 0.71 \\
\hline
\end{tabular}

EGS, Endoscopic Grading System; HGS, Histological Grading System; IBDQ, Inflammatory Bowel Disease Questionnaire.

\section{DISCUSSION}

Heparin is a member of the group of glycosaminoglycans. Presently, it is mainly used in the treatment and prevention of thromboembolic disorders. Its antithrombotic action is achieved through enhancing the activity of antithrombin III and thus inhibiting hemostasis.

However, several other actions of heparin have been discovered. In vitro, there is stimulation of several growth factors, including basic fibroblast growth factor and insulinlike growth factors. ${ }^{21-24}$ Additionally, heparin has been shown to interfere with recruitment, adhesion, and migration of leukocytes. ${ }^{25,26}$

Until recently, heparin therapy has mainly consisted of intravenous application of mixed molecular, unfractionated heparin (UFH). For most indications this has now been replaced by subcutaneous low molecular weight heparin (LMWH).

Only 1 recent article has been published describing the effect of LMWH in the treatment of mild to moderately active

TABLE 5. Adverse Events

\begin{tabular}{lccc}
\hline & $\begin{array}{c}\text { Reviparin } \\
(n=15)\end{array}$ & $\begin{array}{c}\text { Placebo } \\
(n=14)\end{array}$ & $P$ Event \\
\hline Hematoma on injection site & $3(20 \%)$ & $2(14,3 \%)$ & NS \\
Liver enzyme elevation & $1(6.7 \%)$ & 0 & NS \\
Headache & $3(20 \%)$ & $2(14.3 \%)$ & NS \\
Arthralgia & $2(1.3 \%)$ & $1(7.1 \%)$ & NS \\
Nausea & $3(20 \% 0$ & $2(14.3 \%)$ & NS \\
Epistaxis & $1(6.7 \%)$ & $2(14.3 \%)$ & NS \\
\hline
\end{tabular}

NS, not significant. 
UC in a randomized, placebo-controlled manner ${ }^{27}$ and could not detect any significant advantage. Regarding this, 2 earlier controlled studies have been reported, both comparing UFH to corticosteroids. The study by Ang et $\mathrm{al}^{8}$ demonstrated a similar response rate in both groups, with few side effects in the UFH group; in contrast, the study performed by Panes et $\mathrm{al}^{7}$ showed no response in the heparin group and a significantly higher rate of rectal bleeding. The disappointing results of the latter study have been attributed to several factors, including the lack of concomitant 5-ASA therapy and the relatively short treatment period of 10 days. ${ }^{30,31}$ Previous studies with $\mathrm{LMWH}^{11-13}$ had treatment periods of $8-12$ weeks. The administered dose, however, ranged from a low dose of enoxaparin ( $5 \mathrm{mg}$ weekly $)^{11}$ to conventional therapeutic doses of daltoparin and nadroparin. ${ }^{12,13}$ All 3 studies were uncontrolled. Our study was designed in order to maximize the possible effect of the LMWH by continuing the 5-ASA treatment and assuring an adequate duration of treatment. The anticoagulant potency of the dose administered was comparable to that used by Gaffney et $\mathrm{al}^{5,6}$ in their initial publications.

Our results show that the treatment was excellently tolerated but demonstrate no beneficial effect of LMWH in UC. An important observation in this study is the unexpectedly high response in the placebo group of 54\%-85\% (CSG$\mathrm{CAI}$ ) as compared to $9 \%-48 \%$ in other placebo-controlled studies in UC. ${ }^{28,29}$ Possibly this is due to the relatively high proportion of patients with low disease activity at baseline. The demographic and clinical characteristics of the patients in both groups do not offer any other plausible explanation for this outcome, as they were very similar at baseline.

Several explanations have been suggested for the possible beneficial effects of heparin in UC. The finding of microthrombi in rectal biopsies of patients with $\mathrm{UC}^{30}$ combined with the thrombotic tendency in these patients ${ }^{31}$ and the negative correlation between inherited coagulopathies and inflammatory bowel disease ${ }^{32}$ has led to the theory that the anticoagulant property of heparin might be the most important factor. However, Vrij et al ${ }^{13}$ found a high rate of clinical and histologic improvement of inflammation, but no significant change in microvascular thrombi in patients on LMWH therapy. Thus, other anti-inflammatory mechanisms may be involved, such as inhibition of leukocyte adhesion to the vascular endothelium, ${ }^{33}$ interference with transendothelial migration of leukocytes through inhibition of neutrophil elastase, ${ }^{34}$ or stimulation of basic fibroblastic growth factor leading to improved mucosal repair. ${ }^{21}$

The current study (as well as the previously mentioned study by Bloom et $\mathrm{al}^{27}$ ) has not conclusively shown a major efficacy of LMWH in the treatment of UC. Most experimental data are from studies with UFH, which contains a mix of molecules with a range in molecular weight from 3-30 kD. It is possible that the anti-inflammatory effect of heparin is mainly achieved by another fraction than the low molecular one (3-6 kD), in contrast to the anticoagulant effect. Neither UFH and LMWH appear to be sufficiently effective to be used as monotherapy. Possibly there might be a role for heparin as adjuvant therapy to corticosteroids with the intention to delay or even to avoid the need for cyclosporin, anti-TNF $\alpha$, and/or colectomy.

\section{REFERENCES}

1. Mendes de Leon C. [The treatment of acute polyarthritis with heparin]. Ned Tijdschr Geneeskd. 1952;96:2417-2423.

2. Murav'ev Iu V, Samoilova SI. [Heparin treatment of rheumatoid arthritis and systemic lupus erythematosus]. Ter Arkh. 1979;51:48-52.

3. Kartashov IA. [Heparin in the complex treatment of rheumatoid arthritis]. Sov Med. 1977;72-75.

4. Zavgorodnii LG, Mustiats AP. [Use of anticoagulants in the combined treatment of nonspecific ulcerative colitis]. Klin Med (Mosk). 1982;60: $74-80$.

5. Gaffney PR, O'Leary JJ, Doyle CT, et al. Response to heparin in patients with ulcerative colitis. Lancet. 1991;337:238-239.

6. Gaffney PR, Doyle CT, Gaffney A, Hogan J, Hayes DP, Annis P. Paradoxical response to heparin in 10 patients with ulcerative colitis. Am J Gastroenterol. 1995;90:220-223.

7. Panes J, Esteve M, Cabre E, et al. Comparison of heparin and steroids in the treatment of moderate and severe ulcerative colitis. Gastroenterology. 2000;119:903-908.

8. Ang YS, Mahmud N, White B, et al. Randomized comparison of unfractionated heparin with corticosteroids in severe active inflammatory bowel disease. Aliment Pharmacol Ther. 2000;14:1015-1022.

9. Folwaczny C, Wiebecke B, Loeschke K. Unfractioned heparin in the therapy of patients with highly active inflammatory bowel disease. Am J Gastroenterol. 1999;94:1551-1555.

10. Evans RC, Wong VS, Morris AI, Rhodes JM. Treatment of corticosteroid-resistant ulcerative colitis with heparin-a report of 16 cases. Aliment Pharmacol Ther. 1997;11:1037-1040.

11. Dotan I, Hallak A, Arber N, et al. Low-dose low-molecular weight heparin (enoxaparin) is effective as adjuvant treatment in active ulcerative colitis: an open trial. Dig Dis Sci. 2001;46:2239-2244.

12. Torkvist L, Thorlacius H, Sjoqvist U, et al. Low molecular weight heparin as adjuvant therapy in active ulcerative colitis. Aliment Pharmacol Ther. 1999;13:1323-1328.

13. Vrij AA, Jansen JM, Schoon EJ, de Bruine A, Hemker HC, Stockbrugger RW. Low molecular weight heparin treatment in steroid refractory ulcerative colitis: clinical outcome and influence on mucosal capillary thrombi. Scand J Gastroenterol Suppl. 2001;41-47.

14. Lennard-Jones JE. Classification of inflammatory bowel disease. Scand J Gastroenterol Suppl. 1989;170:2-6; discussion 16-19.

15. Truelove S, Witts, LJ. Cortisone in ulcerative colitis: final report on a therapeutic trial. Br Med J. 1955;2:1042-1048.

16. Tytgat G. Comparison of two different oral Mesalazine formulations (Asacol versus Salofalk) in preventing relapses of ulcerative colitis: a dose-ranging, prospective randomized open blinded end-point (PROBE) study. Protocol "Asacol Probe Trial" 1993.

17. Lichtiger S, Present DH, Kornbluth A, et al. Cyclosporine in severe ulcerative colitis refractory to steroid therapy. $N$ Engl J Med. 1994;330: $1841-1845$.

18. Lamme SJ, de Rooij PD, Huijgens PC, Rauwerda JA. [The HITT syndrome: heparin-induced thrombocytopenia and thrombosis as a cause of paradoxically occurring thromboembolisms]. Ned Tijdschr Geneeskd. 1994;138:189-193.

19. Slocum MM, Adams JG Jr, Teel R, Spadone DP, Silver D. Use of enoxaparin in patients with heparin-induced thrombocytopenia syndrome. J Vasc Surg. 1996;23:839-843.

20. Guyatt G, Mitchell A, Irvine EJ, et al. A new measure of health status for clinical trials in inflammatory bowel disease. Gastroenterology. 1989; 96:804-810.

21. Day R, Ilyas M, Daszak P, Talbot I, Forbes A. Expression of syndecan-1 
in inflammatory bowel disease and a possible mechanism of heparin therapy. Dig Dis Sci. 1999;44:2508-2515.

22. Yayon A, Gray TE, Zimmer Y, Eisenstein M, Givol D. Ligand binding by fibroblast growth factor receptors investigated using chimeric receptor molecules. J Recept Signal Transduct Res. 1995;15:185-197.

23. Spivak-Kroizman T, Lemmon MA, Dikic I, et al. Heparin-induced oligomerization of FGF molecules is responsible for FGF receptor dimerization, activation, and cell proliferation. Cell. 1994;79:1015-1024.

24. Arai T, Parker A, Busby W Jr, Clemmons DR. Heparin, heparan sulfate, and dermatan sulfate regulate formation of the insulin-like growth factor-I and insulin-like growth factor-binding protein complexes. $J$ Biol Chem. 1994;269:20388-20393.

25. Bannon PG, Kim MJ, Dean RT, Dawes J. Augmentation of vascular endothelial barrier function by heparin and low molecular weight heparin. Thromb Haemost. 1995;73:706-712.

26. Miller SJ, Hoggat AM, Faulk WP. Heparin regulates ICAM-1 expression in human endothelial cells: an example of non-cytokine-mediated endothelial activation. Thromb Haemost. 1998;80:481-487.

27. Bloom S, Kiilerich S, Lassen MR, et al. Low molecular weight heparin (tinzaparin) vs. placebo in the treatment of mild to moderately active ulcerative colitis. Aliment Pharmacol Ther. 2004;19:871-878.

28. Sandborn WJ, Tremaine WJ, Offord KP, et al. Transdermal nicotine for mildly to moderately active ulcerative colitis. A randomized, doubleblind, placebo-controlled trial. Ann Intern Med. 1997;126:364-371.

29. Stack WA, Jenkins D, Vivet P, Hawkey CJ. Lack of effectiveness of the platelet-activating factor antagonist SR27417A in patients with active ulcerative colitis: a randomized controlled trial. The Platelet Activating Factor Antagonist Study Group in Ulcerative Colitis. Gastroenterology. 1998;115:1340-1345.

30. Dhillon AP, Anthony A, Sim R, et al. Mucosal capillary thrombi in rectal biopsies. Histopathology. 1992;21:127-133.

31. Bernstein CN, Blanchard JF, Houston DS, Wajda A. The incidence of deep venous thrombosis and pulmonary embolism among patients with inflammatory bowel disease: a population-based cohort study. Thromb Haemost. 2001;85:430-434.

32. Thompson NP, Wakefield AJ, Pounder RE. Inherited disorders of coagulation appear to protect against inflammatory bowel disease. Gastroenterology. 1995; 108:1011-1015.

33. Koenig A, Norgard-Sumnicht K, Linhardt R, Varki A. Differential interactions of heparin and heparan sulfate glycosaminoglycans with the selectins. Implications for the use of unfractionated and low molecular weight heparins as therapeutic agents. J Clin Invest. 1998;101:877-889.

34. Walsh RL, Dillon TJ, Scicchitano R, McLennan G. Heparin and heparan sulphate are inhibitors of human leucocyte elastase. Clin Sci (Lond). 1991;81:341-346 